\title{
TINJAUAN YURIDIS TINDAK KEKERASAN ORANG TUA TERHADAP ANAK
}

\author{
Oleh: \\ Gomgom TP Siregar ${ }^{1)}$, \\ Irma Cesilia Syarifah Sihombing ${ }^{2)}$, \\ Universitas Darma Agung, Medan. 1), 2) \\ E-mail: \\ $\frac{\text { gomgomsiregar@gmail.com }}{{ }^{1)}}$,
}

\begin{abstract}
Legal protection for children is all efforts made to create conditions so that each child can exercise his rights and obligations for the development and growth of children naturally, both physically and mentally, social development. Children often become physical victims in the household, physical violence experienced by children is mostly carried out by those closest to the child and many factors cause physical violence against children by parents.To answer this problem, the method used in this research is normative juridical, this method was chosen to find out how the role of legislation regarding legal protection for victims of domestic violence. This type of research uses normative juridical research. Collecting data using literature study method. Victims of violence perpetrated by parents must receive legal protection from a legal, sociological and material perspective. There are several factors that cause violence against children, including economic, environmental and child factors. To prevent physical violence against children, it is necessary to have control, either from the government or from the child's family or parents. One form of overcoming violence against children is to socialize the impact of physical violence against children by parents.
\end{abstract}

Keywords: Children, Physical Violence and Legal Protection.

\section{ABSTRAK}

Perlindungan hukum terhadap anak adalah segala usaha yang dilakukan untuk menciptakan kondisi agar setiap anak dapat melaksanakan hak dan kewajibannya demi perkembangan dan pertumbuhan anak secara wajar baik fisik, mental perkembangan sosial. Anak sering menjadi korban fisik dalam rumah tangga, kekerasan fisik yang yang dialami oleh anak banyak dilakukan oleh orang terdekat anak tersebut dan banyak faktor yang menyebabkan terjadinya kekerasan fisik terhadap anak yang dilakukan oleh orang tua. Untuk menjawab permasalahan tersebut, metode yang digunakan dalam penelitian ini adalah yuridis normatif, metode ini dipilih untuk mengetahui bagaimana peran perundang-undangan mengenai perlindungan hukum terhadap korban kekerasan dalam rumah tangga. Jenis penelitian ini menggunakan penelitian yuridis normatif. Pengumpulan data menggunakan metode studi kepustakaan.Korban kekerasan yang dilakukan oleh 
orang tua harus mendapatkan perlindungan hukum baik dari segi hukum, sosiologis, dan materil. Ada beberapa faktor penyebab terjadinya kekerasan terhadap anak diantaranya karena faktor ekonomi, lingkungan dan anak itu sendiri. Untuk mencegah terjadinya kekerasan fisik terhadap anak perlu adanya penanggulangan, baik itu dari pemerintah maupun dari keluarga atau orang tua anak, salah satu bentuk penanggulangan kekerasan terhadap anak adalah melakukan sosialisasi tentang dampak kekerasan fisik terhadap anak yang dilakukan oleh orangtua.

\section{Kata kunci: Anak, kekerasan fisik dan perlindungan Hukum.}

\section{PENDAHULUAN}

Perlindungan anak adalah segala usaha yang dilakukan untuk menciptakan kondisi agar setiap anak dapat melaksanakan hak dan kewajibannya demi perkembangan dan pertumbuhan anak secara wajar baik fisik, mental dan perkembangan sosial.Yang sangat penting dalam menjaga dan memberikan perlindungan terhadap anak adalah orangtua, keluarga dan lingkungan sekitar tempat tinggal anak.

Anak yang menjadi korban kekerasan menderita kerugian, tidak saja bersifat material, tetapi juga bersifat immaterial seperti goncangan emosional dan psikologis yang dapat mempengaruhi kehidupan masa depan anak. kekerasan sering dialami oleh anak rawan. Disebut rawan adalah karena kedudukan anak yang kurang menguntungkan.Anak rawan adalah anak yang mempunyai resiko besar untuk mengalami gangguan atau masalah dalam perkembangannya baik secara psikologis (mental), sosial maupun fisik.Anak rawan dipengaruhi oleh kondisi internal maupun kondisi eksternalnya, diantaranya adalah anak dari rumah.

Mengingat dengan banyaknya terjadi kasus kekerasan terhadap anak, KPAI (Komisi Perlindungan Anak Indonesia) mengungkapkan bahwa sejak Januari-Juni 2020 terdapat 3.296 anak perempuan dan anak laki-laki 1.319 menjadi korban kekerasan selama rentan waktu tersebut, baik itu kekerasan fisik, seksual maupun kekerasan emosional. Dari jumlah tersebut, 1.111 anak mengalami kekerasan fisik, 979 anak mengalami kekerasan psikis, 2.556 anak menderita kekerasan seksual, 68 anak menjadi korban eksploitasi, 73 anak menjadi korban perdagangan orang, dan 346 anak menjadi korban penelantaran. pemerintah kita telah menerbitkan peraturan perundang-undangan yang secara khusus mengatur tentang perlindungan anak yaitu undangundang Nomor 23 Tahun 2002 yang telah digantikan menjadi Undangundang No 35 tahun 2014 tentang perlindungan anak. Dengan adanya peraturan perundang-undangan ini tindak kejahatan terhadap anak diharapkan dapat berkurang dan perlindungan terhadap keselamatan anak dapat terjamin.

Anak yang menjadi korban kekerasan fisik dalam keluarga perlu diperhatikan khususnya orangtua.Perlindungan hukum harus diberikan sebaik mungkin untuk menjamin hak-hak anak tersebut. Ada beberapa bentuk perlindungan hukum terhadap anak yang menjadi korban kekerasan fisik dalam rumah tangga, yaitu: 
a. Pemberian restitusi dan kompensasi

Restitusi adalah ganti kerugian yang diberikan kepada korban atau keluarganya oleh pelaku atau pihak ketiga. Restitusi dapat berupa :

- Pengembalian harta milik.

- Pembayaran ganti kerugian untuk kehilangan atau penderitaan.

- Penggantian biaya untuk tindakan tertentu.

Sedangkan kompensasi adalah ganti kerugian yang diberikan oleh Negara karena pelaku tidak mampu memberikan ganti kerugian sepenuhnya yang menjadi taggung jawabnya.

b. Konseling

Pada umumnya perlindungan ini diberikan kepada korban akibat munculnya dampak negatif yang sifatnya psikis dari suatu tindak pidana pemberian bantuan dalam bentuk konseling sangat cocok diberikan kepada korban kejahatan yang menyisakan trauma berkepanjangan, seperti pada kasus-kasus menyangkut kesusilaan dan kekerasan fisik.

c. Pelayanan atau Bantuan Medis

Pelayanan atau bantuan medis ini merupakan kepada korban yag menderita secara medis akibat suatu tindak pidana. Pelayanan medis yang dimaksud dapat berupa pemeriksaan kesehatan dan laporan tertulis (visum) atau surat keterangan medis yang memiliki kekuatan hukum yang sama dengan alat bukti. Keterangan medis ini diperlukan terutama apabila korban hendak melaporkan kejahatan yang menimpanya ke aparat kepolisian untuk ditindaklanjuti.

d. Bantuan hukum

Bantuan hukum merupakan suatu bentuk pendampingan terhadap korban kejahatan.Di Indonesia bantuan ini banyak diberikan oleh Lembaga Swadaya Masyarakat (LSM).

\section{TINJAUAN PUSTAKA}

Menurut Kamus Besar Bahasa Indonesia (KBBI) yang dimaksud dengan anak adalah keturunan atau manusia yang masih kecil. Sedangkan dalam pengertian sehari-hari yang dimaksud dengan anak adalah yang belum mencapai usia tertentu atau belum kawin. Pengertian ini seringkali dipakai sebagai pedoman umum. Apabila ditinjau dari aspek yuridis ,maka pengertian anak dimata hokum positif Indonesia lazim diartikan sebagai orangtua yang belum dewasa,yang dibawah umur atau keadaan dibawah umur atau kerap juga disebut sebagai anak dibawah pengawasan wali.

a. Pasal 1 ayat (1) UndangUndang No.3 tahun 1997 tentang pengadilan anak,menyatakan bahwa anak adalah orang yang dalam perkara anak nakal telah mencapai umur 8 tahun tetapi belum mencapai 18 tahun dan belum pernah kawin.

b. Pasal 1 angka 5 UndangUndang No.39 tahun 1999 tentang Hak Asasi Manusia, menyatakan anak adalah setiap manusia yang berusia 
di bawah umur 18 tahun dan belum menikah,termasuk anak yang dalam kandungan apabila hal tersebut adalah demi kepentingannya.

c. Pasal 1 ayat (1) UndangUndang No.35 tahun 2014 menyatakan anak adalah seseorang yang belum berumur 18 tahun, termasuk anak yang masih dalam kandungan.

Menurut undang-undang, kekuasaan orangtua terhadap pribadi seorang anak diatur secara otentik di dalam Kitab Undang-Undang Hukum Perdata, yaitu:

a. Pasal 298 menegaskan bahwa tiap-tiap anak, dalam umur berapun juga, wajib menaruh kehormatan dan keseganan terhadap bapak dan ibunya. Bapak dan ibunya berkewajiban memelihara dan mendidik anak-anak mereka yang belum dewasa kehilangan hak untuk memangku kekuasaan orangtua atau untuk menjadi wali tidak membebaskan mereka dari kewajiban, memberi tunjangan-tunjangan dalam keseimbangan dengan pendapatan mereka, guna membiayai pemeliharaan dan pendidikan itu.

b. Pasal 299 menyebutkan bahwa sepanjang perkawinan bapak dan ibu, tiap-tiap anak sampai menjadi dewasa tetap bernaung di bawah kekuasaan mereka. Selama mereka tidak dibebaskan atau dipecat dari kekuasaan itu.

c. Adapun pasal 301 menegaskan bahwa dengan tidak mengurangi apa yang ditentukan dalam hal pembubaran perkawinan setelah berlangsungnya perpisahan meja dan ranjang, berwajiblah si bapak dan ibu, pun sekiranya mereka tidak memangku kekuasaan orangtua sedangkan tidak pula dibebaskan atau dipecat dari itu, guna keperluan pemeliharaan dan pendidikan anak-anak mereka yang belum dewasa,tiap-tiap minggu, tiap-tiap bulan atau tiap 3 bulan, menyampaikan tunjangan mereka kepada dewan perkalian sedemikan banyak sebagaimana atas tuntutan dewan pengadilan negeri berkenan menentukannya.

Pada hakekatnya, pengertian anak dan status kedudukan anak dalam hukum pidana meliputi dimensi-dimensi sebagai berikut :

a. Ketidakmampuan untuk pertanggungjawaban tindak pidana.

b. Pengembalian hak-hak anak dengan jalan membsubsitusikan hak-hak anak yang timbul dari lapangan hukum keperdataan, tata negara, dan hukum kekuasaan dengan maksud untuk mensejahterakan anak.

c. Rehabilitasi yaitu anak berhak untuk mendapat proses perbaikan mental spiritual akibat dari tindakan hukum pidana yang dilakukan oleh anak itu sendiri.

d. Hak-hak untuk menerima pelayanan dan asuhan.

e. Hak anak dalam proses hukum acara pidana. 
1. Konvensi Hak Anak

Hak anak merupakan bagian internal dari hak asasi manusia dankonvensi Hak Anak (KHA) merupakan bagian integral dari instrumen internasional tentang hak asasi manusia. Konvensi Hak Anak merupakan instrumen yang berisi rumusan prinsip-prinsip universal dan ketentuan norma hukum mengenai hak-hak anak yang merupakan sebuah perjanjian internasional mengenai hak asasi manusia yang memasukkan unsurunsur hak-hak sipil dan politik serta hak-hak ekonomi, sosial, dan budaya.

Indonesia meratifikasi KHA melalui Keputusan Presiden Nomor36 Tahun 1990 tertanggal 25 Agustus 1990. Dengan ratifikasi tersebut, Indonesia secara teknis telah dengan sukarela mengikatkan diri kepada ketentuan-ketentuan yang terkandung dalam KHA. Sesuai dengan pasal 49 ayat (2)Konvensi Hak Anak dinyatakan diberlakukan di Indonesia sejak tanggal 5 Oktober 1990.

Ketentuan yang menyangkut hak-hak anak yang tercakup dalam konvensi terdapat pada bagian I. Oleh komite Hak Anak PBB, ketentuan-ketentuan menyangkut hak ini diklasifikasikan menjadi 8 kelompok, yaitu :
a. Langkah-langkah implementasi umum
b. Defenisi anak
c. Prinsip-prinsip Hukum Hak Konvensi Anak
d. Hak Sipil dan Kebebasan
e. Lingkungan keluarga dan pengasuhan Alternatif
f. Kesehatan dan kesejahteraan Dasar
g. Pendidikan, waktu luang dan kegiatan budaya
h. Langkah-langkah perlindungan khusus.

\section{METODE PENELITIAN}

Metode penelitian dapat diartikan sebagai satu cara atau teknis yang dilakukan dalam proses penelitian,sedangkan penelitian adalah suatu upaya dalam bidang ilmu pengetahuan yang dijalankan untuk memeperoleh fakta-fakta dan prinsip-prinsip dengan sabra dan hati-hati dan sistematis untuk mewujudkan kebenaran.

Dalam hal ini menggunakan penelitian yuridis normatiF atau penelitian doktrial,yaitu penelitian yang dilakukan atau ditujukan untuk mengkaji isi peraturan-peraturan yang tertulis atau bahan-bahan hukum lainnya. Berdasarkan jenis datanya maka yang menjadi sumber data dalam penelitian ini adalah sumber data dalam penelitian ini adalah sumber data sekunder dengan cara mempelajari dan menganalisa bahan hukum. Dalam penelitian ini dikelompokkan menjadi bahan Hukum Primer, yaitu bahan hukum yang mengikat dan terdiri dari Kitab Undang-Undang Hukum Pidana (KUHP) dan Kitab Undang-Undang Hukum Perdata (KUH)perdata, Konvensi hak anak, Undang-Undang No.39 Tahun 1999 tentang Hak Asasi Manusia, UU No.35 tahun 2014 Tentang perlindungan Anak, dan ,menggunakan bahan hukum sekunder merupakan data penunjang yang berupa sumber-sumber tulisan lain yang diperoleh melalui segala sumber kepustakaan diluar data primer yang telah disebutkan.

Langkah yang dilakukan setelah mengumpulkan data adalah menganalisis data yang sudah berhasil dikumpulkan tersebut,selanjutnya dilakukan 
editing dan secukupnya untuk mengetahui apakah data tersebut benar,sudah lengkap atau masih ada kekurangan yang harus disempurnakan. Karena sifat penelitian ini adalah deskriptif, maka analisis yang dilakukan hanya bertujuan untuk memberi gambaran dalam prakteknya, terhadap permasalahan yang ingin dijawab.

\section{HASIL DAN PEMBAHASAN}

\section{A. Faktor \\ Penyebab \\ Terjadinya \\ Kekerasan \\ Terhadap Anak Yang \\ Dilakukan Oleh Orangtua}

Tindakan kekerasan dapat terjadi sebagai bagian dari tindakan manusia untuk melampiaskan rasa amarah yang sudah tak tertahankan lagi. Terkadang kekerasan dianggap sebagai sebuah tindakan yang normal unruk dilakukan, namun tindakan yang sama pada situasi yang berbeda tidak dapat dikatakan normal, tetapi disebut sebagai penyimpangan.

Terjadinya kekerasan terhadap anak dapat dipengaruhi oleh faktor internal dan faktor eksternal :

1. Faktor internal

a) Berasal dari diri anak

Terjadinya kekerasan terhadap anak dapat disebabkan oleh tingkah laku anak. Kondisi tersebut misalnya: Anak menderita gangguan perkembangan,

ketergantungan anak pada lingkungannya, anak mengalami cacat tubuh, retardasi mental, gangguan tingkah laku, anak yang mengalami perilaku menyimpang dan tipe kepribadian dari anak itu sendiri.

b) Keluarga/orang tua

Faktor orang tua atau keluarga memegang peranan penting terhadap terjadinya kekerasan pada anak. Beberapa contih seperti orang tua yang memiliki pola asuh membesarkan anaknya dengan kekerasan atau penganiaayaan, keluarga yang sering bertengkar mempunyai tingkat tindakan kekerasan terhadap anak yang lebih tinggi dibandingkan keluarga yang tanpa masalah, orang tua tunggal lebih memungkinkan

melakukan tindakan kekerasan terhadap anak karena faktor stress yang dialami oleh orang tua tersebut, riwayat orang tua dengan kekerasan pada masa kecil juga memungkinkan

melakukan kekerasan pada anaknya.

2. Faktor Eksternal

a) Lingkungan Luar

Kondisi lingkungan juga dapat menjadi penyebab terjadinya kekerasan terhadap anak, diantaranya seperti kondisi lingkungan yang buruk.Terdapat sejarah pelantaran anak, dan tingkat kriminalitas yang tinggi dalam lingkungannya.

b) Media Massa

Media massa merupakan salah satu alat informasi. 
\begin{tabular}{lrr} 
Media massa & telah \\
menjadi & bagian & dari \\
kehidupan & \multicolumn{2}{c}{ manusia } \\
sehari-hari & dan & media \\
massa & ini & tentu
\end{tabular}

memengaruhi penerimaan konsep, sikap, nilai, dan pokok moral. Seperti halnya dalam media cetak menyediakan berita-berita tentang kejahatan, kekerasan, pembunuhan.Kemudian media elektronik menampilkan adegan kekerasan, menayangkan film action dengan perkelahian, acara berita kriminal, penganiayaan, kekerasan bahkan pembunuhan dalam lingkup keluarga. Pada hakekatnya media massa memiliki fungsi yang positif, namun kadang dapat menjadi negatif.

c) Budaya

Budaya yang masih menganut praktek-praktek dengan pemikiran bahwa status anak yang dipandang rendah sehingga ketika anak tidak dapat memenuhi harapan orang tua maka anak harus dihukum. Bagi anak laki-laki, adanya nilai dalam masyarakat bahwa anak laki-laki tidak boleh cengeng atau anak laki-laki harus tahan uji.pemahaman itu mempengaruhi dan membuat orang tua ketika memukul, menendang, atau menindas anak adalah suatu hal yang wajar untuk menjadikan sebagai pribadi yang kuat dan tidak boleh lemah.

Menurut Rusmil penyebab kekerasan pada anak tersebut adalah terdiri dari 3 faktor, yaitu faktor orangtua/keluarga, faktor lingkungan sosial/komunitas, dan faktor yang berasal dari anak. Berikut dipaparkan beberapa hal yang dapat menyebabkan terjadinya kekerasan pada anak, yaitu :

a. Kurangnya pemahaman tentang kekerasan.

Diantara masyarakat masih banyak yang memiliki pemahaman yang salah tentang kekerasan. Masyarakat kurang memahami bahwa hal-hal yang mereka lakukan seperti menampar atau memukul anak adalah kekerasan yang tidak boleh dilakukan.

b. Ketidakpahaman dalam menghukum anak.

Menurut pemahaman sebagian dari masyarakat bahwa kekerasan adalah sebuah hal yang sangat wajar dilakukan terutama ketika anak melakukan kesalahan. Kekerasan dilakukan terhadap anak dianggap sebagi sebuah upaya dalam mendidik anak.

c. Ketidaksabaran orang dewasa ketika berhadapan dengan masalah anak.

Para pihak yang berkaitan dengan anak kerap tidak bisa mengontrol emosinya terutama ketika akan melakukan kesalahan.

d. Kurangnya pemahaman tentang akibat kekerasan fisik dan psikis terhadap anak.

Kekerasan terhadap anak sangat berdampak buruk pada 
anak, namun banyak masyarakat tidak memahami hal ini, sehingga kekerasan terhadap anak kian meningkat.

e. Kurangnya kesadaran hukum masyarakat mengenai hakhak anak.

Banyak masyarakat yang tidak mengetahui bahwa hakhak anak diatur dalam peraturan perundangundangan, bahkan pelaku kekerasan terhadap anak dapat dipidana.

Kebutuhan terhadap perlunya perlindungan hukum terhadap anak dapat mencakup berbagai bidang/aspek, antara lain:

a. Perlindungan terhadap hakhak asasi dan kebebasan anak.

b. Perlindungan anak dalam proses peradilan.

c. Perlindungan Kesejahteraan anak (dalam lingkungan keluarga, pendidikan, dan lingkungan sosial).

d. Perlindungan anak dalam masalah penahanan dan perampasan kemerdekaan.

e. Perlindungan anak dari segala bentuk eksploitasi (perbudakan,perdagangan anak, pelacuran, pornografi), perdagangan/penyalahgunaan obat-obatan, memperalat anak dalam melakukan kejahatan dan sebagainya.

f. Perlindungan anak-anak jalanan.

g. Perlindungan anak dari akibat-akibat peperangan/konflik bersenjata.

h. Perlindungan anak terhadap tindakan-tindakan kekerasan.
Perlindungan hukum bagi anak dapat diartikan sebagai upaya perlindungan hukum terhadap berbagai kebebasan dan hak asasi anak (fundamental rights and freedoms of children) serta berbagai kepentingan yang berhubungan dengan kesejahteraan anak. Jadi masalah perlindungan hukum bagi anak mencakup lingkup yang sangat luas. Aspek hukum perlindungan bagi anak adalah bahwa semua kebijakan legislatif (produk perundang-undangan) yang berkaitan dengan anak harus bermuara pada penegakan kebebasan anak, penegakan hak asasi anak, dan terwujudnya kesejahteraan anak. Aspek hukum perlindungan anak, lebih dipusatkan kepada hak-hak anak yang diatur hukum bukan kewajiban, mengingat secara hukum (yuridis) anak belum dibebani kewajiban.

Perlindungan hukum bagi anak menyangkut banyak hal. Pertemuan ahli PBB (United Nations Expert Group Meeting) di Vienna, Austria yang berlangsung pada tahun 1994, lebih menekankan pada masalah-masalah berikut:

a. Masalah Working Children.

Hal yang menjadi perhatian dan prihatinkan disini adalah anak-anak yang menjadi pekerja penuh, perdagangan anak, perbudakan anak, dan pornografi yang diakibatkan oleh meningkatnya Sex tourisme.

b. Masalah Street Children. Banyak anak anak diseluruh dunia yang harus hidup sebagai anak jalanan. Yang sangat memprihatinkan adalah bahwa mereka berjuang sendiri demi mempertahankan hidupnya. 
Anak-anak jalanan juga menjadi sasaran para pelaku penyalahgunaan narkotika dan obat-obatan terlarang serta pelaku eksploitasi anak.

c. Masalah Children in armed conflict.

Dalam situasi konflik tidak sedikit anak-anak yang menjadi korban. Ada yang luka, cacat, bahkan meninggal dunia. Kalaupun hidup sebagian besar dari mereka tidak akan dapat berkumpul dengan keluarganya.

d. Masalah urban war zones.

Suasana kekerasan dan ketidaktentraman yang terjadi dalam lingkungan anak-anak sehari-harinya, akan menimbulkan suasana peperangan. Anak-anak akan hidup dengan resiko yang sangat gawat dan kronis. Apalagi kondisi tersebut dibarengi dengan meningkatkan kejahatan khususnya penyalahgunaan narkotika.

a. Masalah the instrumental of children.

Anak-anak sangat rentan menjadi pelaku kejahatan, karena anak begitu mudahnya diperalat, diiming-imingi janji, atau dibujuk rayu. Sehingga berakibat anak-anak kerap diperalat oleh orang dewasa untuk melakukan kejahatan.

\section{B. Upaya Penanggulangan Kekerasan Terhadap Anak Yang Dilakukan Oleh Orangtua}

Perbuatan dan langkah
pencegahan kekerasan pada anak secara komprenhensif ke dalam sistem peradilan. Sistem hukum yang ada, ada baik peradilan anak, pidana dan perdata, seluruh peraturan dan prosedurnya harus sedemikian rupa sehingga sensitif dengan kebutuhan anak dan keluarga. Tentu dalam hal ini harus ditunjang pula dengan jumlah tenaga hakim, pengacara, staf pengadilan terlatih yang memadai. Bagi masyarakat, keluarga, atau orang tua diperlukan kebijakan, layanan, sumberdaya, dan pelatihan pencegahan kekerasan pada anak yang konsisten dan terus menerus. Upaya pencegahan ini meliputi :

1. Pencegahan Primer

Pencegahan primer dilakukan untuk semua orang tua dalam upaya meningkatkan kemampuan pengasuhan dan menjaga agar perlakuan salah atau abuse tidak terjadi, meliputi perawatan anak dan layanan yang memadai, kebijakan tempat bekerja yang mendukung, serta pelatihan life skillbagi anak. Yang dimaksud dengan pelatihan life skill meliputi penyelesaian konflik tentang kekerasan, keterampilan menangani stress, management sumber daya, membuat keputusan efektif, komunikasi interpersonal secara efektif, tuntunan atau guidancedan perkembangan anak, termasuk penyalahgunaan narkoba.

2. Pencegahan sekunder Pencegahan sekunder ditujukan bagi kelompok masyarakat dengan risiko tinggi dalam upaya meningkatkan keterampilan pengasuhan, termasuk pelatihan dan layanan korban untuk menjaga agar perlakuan salah tidak terjadi pada generasi berikut. Kegiatan yang dilakukan disini diantaranya dengan melakukan kunjungan rumah bagi 
rang tua yang baru mempunyai anak yang melakukan self assesment apakah mereka melakukan kekerasan pada anak di kemudian hari.

3. Pecegahan Tersier Pencegahan tersier dimaksudkan untuk meningkatkan kemampuan pengasuhan yang menjaga agar perlakuan salah tidak terulang kembali, disini yang dilakukan adalah layanan terpadu untuk anak yang mengalami korban kekerasan, konseling, pelatihan tata laksana stress.

Banyak cara yang dilakukan untuk pencegahan kekerasan terhadap anak dalam rumah tangga, berikut ini adalah berupa bentukbentuk pencegahan agar tidak terjadi kekerasan fisik terhadap anak yang dilakukan oleh orangtua :

a. Pendidikan dan Pengetahuan Orang Tua Yang Cukup

Dari beberapa faktor yang telah dibahas, maka perlu kita ketahui bahwa tindak kekerasan terhadap anak sangat berpengaruh terhadap perkembangannya baik psikis maupun fisik mereka. Oleh karena itu, perlu kita hentikan tindak kekerasan tersebut. Dengan pendidikan yang lebih tinggi dan pengetahuan yang cukup diharapkan orantua mampu mendidik anaknya ke arah perkembangan yang memuaskan tanpa adanya tindak kekerasan.

b. Keluarga Yang Hangat Dan Demokraktis

Dalam sebuah study yang dilakukan oleh R.Study (Jerman) terbukti bahwa IQ anak yang tinggal di rumah yang orangtuanya acuh tak acuh, bermusuhan dan keras, atau broken home, perkembangan IQ anak mengalami penurunan dan masa tiga tahun. Sebaliknya anak yang tinggal di rumah yang orangtuanya penuh pengertian, bersikap hangat, penuh kasih sayang dan menyisihkan waktunya untuk berkomunikasi dengan anak-anakny, menjelaskan tindaknya, memberi kesempatan anak untuk mengambil keputusan, berdialog dan diskusi, hasilnya ratarata IQ (bahkan kecerdasan emosi) anak mengalami kenaikan. Hasil penelitian R.Study juga membuktikan bahwa $63 \%$ dari anak nakal pasa suatu lembaga pendidikan anak-anak dilenkuen (nakal), berasal dari keluarga yangtidak utuh (broken home). Kemudian hasil penelitian K.Gottsschaldt di Leipzig (Jerman) menyatakan bahwa 70,8 \% dari anakanak yang sulit di didik ternyata berasal dari keluarga yang tidak teratur, tidak utuh atau mengalami tekanan hidup terlampau berat.

\section{c. Membangun Komunikasi Yang Efektif}

Kunci persoalan kekerasan terhadap anak disebabkan karena tidak adanya komunikasi yang efektif dalam sebuah keluarga. Sehinggayang muncul adalah streotyping (stigama) dan predijuce (prasangka). Dua hal itu kemudian mengalami proses akumulasi yang kadang di bumbui intervensi pihak ketiga.

Sebagai contoh kasus dua putri kandung pemilik sebuah pabrik rokok di Malang Jawa Timur. Amy Victoria Chan (10) dan Ann Jesica Chan (9) diduga jadi korban kekerasan dari ibu kandung mereka saat bermukim di Kanada. Ayahnya terlambat tahu karena sibuk mengurus bisnis dan hanya sesekali mengunjungi mereka. Merek dituntut ibunya agar meraih prestasi di segala bidang sehingga wakt mereka dipenuhi kegiatan belajar dan beragam kursus seperti balet, kumon, piano. Jika tidak bersedia, mereka 
disiksa dengan segala cara mereka juga pernah dibiarkan berada di luar rumah saat musim dingin. Kejadian ini mungkin tidak terjadi jika ayahnya selalu mendampingi anakanaknya.

Hambatan dalam upaya penanggulangan kekerasan terhadap anak antara lain:

a. Kurangnya minat masyarakat dan orang tua dalam mengikuti penyuluhan tentang faktor dan dampak kekerasan anak.

b. Kurangnya masyarakat ataupu orang tua dalam menanggapi tentang kekerasan anak. Hal ini karena menurut orang tua ataupun masyarakat tidak menganggap serius dampak dari kekerasan anak.

c. Kurangnya pendidikan orang tua yang menyebabkan kurangnya pengertahuan orang tua yang tidak mengetahui mencegah kekerasan anak ataupun dampak dari kekerasan anak.

d. Tidak pedulinya masyarakat dalam terjadinya kekerasan terhadap anak, karena banyaknya masyarakat yang membiarkan terjadinya kekerasan terhadap yang terjadi di masyarakat itu sendiri.

Terkait dengan pihak-pihak, peran dan tanggung jawab masingmasing dalam upaya memberikan perlindungan terhadap anak dapat dilihat dalam beberapa pasal yang ada dalam Undang-Undang perlindungan Anak sebagai berikut:

1. Kewajiban dan tanggung jawab Negara dan Pemerintah dan Pemerintah Daerah.

Negara, Pemerintah dan Pemerintah Daerah berkewajiban untuk memenuhi, melindungi dan menghormati hak anak, berkewajiban dan bertanggung jawab dalam merumuskan dan melaksanakan kewajiban menyelenggarakan perlindungan anak. Berkewajiban dan bertanggung jawab dalam memberikan dukungan sarana, prasarana ketersediaan sumber daya manusia Dalam penyelenggaraan perlindungan anak dari kekerasan.

2. Kewajiban dan Tanggung Jawab Masyarakat

Kewajiban dan tanggung jawab masyarakat dilaksanakan melalui kegiatan peran masyarakat dan menyelenggarakan perlindungan Anak. Peran masyarakat (baik perorangan, lembaga perlindungan anak, lembaga kesejahteraan sosial, organisasi masyarakat, lembaga pendidikan) dilakukan dengan cara memberikan informasi melalui sosial media dan edukasi mengenai hak anak dan peraturan perundangundangan tentang anak, memberikan masukan dalam rumusan kebijakan terkait perlindungan anak, melaporkan kepada pihak berwenang jika terjadinya kekerasan anak ataupun pelanggaran hak anak, berperan aktif dalam rehabilitas dan reintegrasi sosial anak yaitu dengan melakukan pengawasan dan ikut bertanggung jawab terhadap penyelenggaraan perlindungan anak, menyediakan saran dan prasarana serta menciptakan suasana kondusif untuk tumbuh kembang anak. Berperan aktif dengan menghilangkan pelebelan negatif terhadap anak korban dan memberikan ruang kepada anak untuk dapat berpartisipasi dan menyampaikan pendapat.

a. Peran media massa dilakukan melalui menyebarluaskan informasi dan materi edukasi yang bermanfaat dari aspek sosial, budaya, pendidikan, agama dan kesehatan anak 
dengan memperhatikan kepentingan terbaik bagi anak.

b. Peran dunia usaha dilakukan dengan melalui kebijakan perusahaan yang berperspektif anak, produk yang ditujukan untuk anak harus aman bagi keselamatan anak, berkontribusi dalam pemenuhan hak anak melalui tanggung jawab sosial perusahaan.

3. Kebijakan dan Tanggung Jawab Keluarga dan Orang Tua

Kewajibannya yaitu dengan mengasuh, memelihara, mendidik dan melindungi anak, menumbuhkan kembang anak sesuai dengan kemampuan bakat, dan minatnya, mencegah dengan terjadinya pendidikannya kekerasan anak, perkawinan pada usia anak yang memberikan pendidikan karakter dan penanaman nilai budi pekerti pada anak. Dalam hal ini orang tua tidak ada atau tidak diketahui keberadaannya atau karena suatu sebab tidak dapat dapat melaksanakan kewajiban dan tanggung jawabnya, kewajiban dan tanggung jawabnya dapat beralih kepada keluarga yang ditentukan sesuai dengan peraturan perundangundangan.

\section{SIMPULAN}

Berdasarkan hasil dari pembahasan yang telah diuraikan diatas, penulis berkesimpulan

1. Faktor penyebab kekerasan terhadap anak adalah terdiri dari 2 faktor yaitu, Faktor internal dan faktor eksternal yang meliputi: Berasal dari diri anak, Terjadinya kekerasan terhadap anak dapat disebabkan oleh tingkah laku anak. anak yang mengalami perilaku menyimpang dan tipe kepribadian dari anak itu sendiri, Keluarga/orang tuaseperti orang tua yang memiliki pola asuh membesarkan anaknya dengan kekerasan atau penganiaayaan. Lingkungan Luar,kondisi lingkungan yang buruk. Terdapat sejarah pelantaran anak, dan tingkat kriminalitas yang tinggi dalam lingkungannya. Media Massa, Media massamenyediakan beritaberita tentang kejahatan, kekerasan, pembunuhan. Kemudian media elektronik menampilkan adegan kekerasan, menayangkan film action dengan perkelahian, acara berita kriminal, penganiayaan, kekerasan bahkan pembunuhan dalam lingkup keluarga. Budaya yang masih menganut praktek-praktek dengan pemikiran bahwa status anak yang dipandang rendah sehingga ketika anak tidak dapat memenuhi harapan orang tua maka anak harus dihukum.

2. Perlindungan hukum terhadap anak sebagai korban kekerasan yang dilakukan oleh orang tua adalah Undang-Undang Nomor 23 Tahun 2002 meletakkan kewajiban memberikan perlindungan kepada anak berdasarkan asas-asas:Asas Nondiskriminasi, Asas Kepentingan yang Terbaik Bagi Anak, Asas Hak untuk Hidup, Kelangsungan Hidup, 
dan PerkembanganAsas yang mendasarkan pada hak untuk hidupAsas Penghargaan terhadap Pandangan/Pendapat Anak.

3. Upaya penanggulangan kekerasan terhadap anak dibagi menjadi 2 pendekatan yaitu, Pendekatan Kuratif merupakan pendekatan yang menyelenggarakan

pendidikan orang tua untuk dapat menerapkan cara mendidik dan memperlakukan anakanaknya secara humanis dan Pendekatan kuratif merupakan upaya yang dilakukan secara dini melalui kegiatan edukatif dengan sasaran mempunyai faktorfaktor penyebab pendorong dan faktor peluang dari kejahatan kekerasan dalam rumah tangga, sehingga terciptanya suatu kesadaran.

\section{DAFTAR PUSTAKA}

A. Buku

A.Gunawan Setiardja. Hak-Hak Azasi Manusia Berdasarkan Ideologi Pancasila. Kanisius, Yogyakarta, 1993.

Agung Wahyono dan Siti Rahayu. Tinjauan Tentang Peradilan Anak di Indonesia. Jakarta: Sinar Grafika: Jakarta, 1993.

Arif Gosita, Masalah Perlindungan Anak, Akademi Pressindo, 1989.

Aminah, Aziz. Masalah Perlindungan Anak, USU Press, Medan:1989.
Gultom, Maidin. Perlindungan Hukum Terhadap Anak dalam Sistem Peradilan Pidana Anak di Indonesia, Refika Aditama, Bandung: 2010.

Hadi Setia Tunggal (Ed). Konvensi Hak-hak Anak (Convention the Rights Of The Child). Harvarindo, Jakarta: 2002.

Helen Cowie dan Dawn Jennifer.penanganan

Kekerasan di Sekolah Pendekatan Lingkup Sekolah Untuk Mencapai Praktik Terbaik, Indeks, Jakarta: 2007.

Huraerah, Abu.Kekerasan Terhadap Anak, Bandung: Nuansa Cendekia, 2012.

I.Marsana Windhu. 1999. Kekerasan Terhadap Anak, dalam wacana dan Realita. Pusat kajian Perlindungan Anak (PKPA).

Muhammad Joni dan Zulchaina Z. Tanamas. Aspek Hukum Perlindungan Anak dalam Perspektif Konvensi Hak Anak, Citra Aditya Bakti, Bandung:2000.

Soemitro, Ima Setyowati. Aspek Hukum Perlindungan Anak, Jakarta:Bumi Aksara, 1990.

Waluyadi. Hukum Perlindungan anak. Mandar Maju, Bandung:2009.

Yesmil Anwar dan Adang, 2010, Kriminologi, Refika Aditama, Bandung

Peraturan perundang-undangan dan peraturan lainnya 
Kitab Undang-Undang Hukum

Perdata.

Kitab Undang-undang Hukum

Pidana.

Undang-Undang Nomor 35 Tahun

2014 tentang perbahan Atas

Undang-Undang Nomor 23

Tahun 2002 Tentang

Perlindungan Anak.

Undang-undang Nomor 03 Tahun

2009 tentang Peradilan Anak. 